\title{
Acute polyradiculoneuropathy complicating systemic lupus erythematosus
}

\author{
Stephen H. Morgan, Robin P. Kennett, Christopher Dudley, Charles Mackworth- \\ Young, Richard Hull and Graham R.V. Hughes*
}

\author{
The Rheumatology and Neurology Units, The Royal Postgraduate Medical School, Hammersmith Hospital, \\ London W12, UK.
}

\begin{abstract}
Summary: Two elderly patients with systemic lupus erythematosus (SLE) are presented. Both developed an acute polyradiculoneuropathy which is an unusual complication of this disease. Features of their presentation are discussed.
\end{abstract}

\section{Introduction}

The neurological manifestations of systemic lupus erythematosus (SLE) may be protean (Johnson \& Richardson, 1968). Cerebral involvement was a feature of one of the earliest patients described by Kaposi (1872), but peripheral nerve disorders are seen much less frequently. In a recent prospective study of patients presenting with SLE to the Hammersmith Hospital (Grigor et al., 1978), 3 patients (6\%) had a peripheral neuropathy but only 1 was an ascending polyradiculoneuropathy of the Guillain-Barré type. We now document 2 patients who have presented with this complication of SLE in the last year.

\section{Case reports}

\section{Case 1}

A 58 year old male psychotherapist first developed an acute symmetrical polyarthropathy in 1982 . This was in a rheumatoid distribution, and improved on treatment with indomethacin.

In 1984 there was a recurrence of arthritis with fever and night sweats. He was again treated with indomethacin, but a few weeks later developed visual hallucinations, poor concentration, anorexia and weight loss. A month later progressive weakness of both legs became apparent, with numbness and tingling of the ex-

\footnotetext{
*Present address: Rheumatology Department, St Thomas' Hospital, Lambeth Palace Rd, London S.E.1, UK.

Correspondence: S.H. Morgan, M.B., M.R.C.P., Division of Inherited Metabolic Diseases, Clinical Research Centre, Northwick Park Hospital, Harrow, Middlesex, UK.

Accepted: 24 September 1985
}

tremities. Over the next week similar symptoms developed in the arms. Past history included chorea in childhood and more recently, grittiness of the eyes and pleuritic chest pains.

When examined in 1984 he looked ill. There was a synovitis of the small joints of both hands and feet. There was marked facial diplegia but no other bulbar signs. There was a flaccid and global weakness of all limbs, in the MRC grading range 2-3. The truncal muscles were too weak to flex the body against gravity. There was hypaesthesia and hypalgesia of the fingers and below the knees bilaterally. Position sense was impaired in the fingers and toes, and vibration sense was lost below the anterior superior iliac spines. There was no evidence of sphincter or autonomic disfunction.

Investigations showed a hypochromic normocytic anaemia (haemoglobin $8.6 \mathrm{~g} / \mathrm{dl}$ ) and thrombocytopenia $\left(114 \times 10^{6} / 1\right)$. The biochemical renal function was impaired (creatinine $160 \mu \mathrm{mol} / \mathrm{l}$, urea $15.8 \mathrm{mmol} / \mathrm{l}$, creatinine clearance $27 \mathrm{ml} /$ minute). There was $3.2 \mathrm{~g}$ of proteinuria/24 hours. The ESR was $108 \mathrm{~mm} /$ hour and C-reactive protein (CRP) $2.0 \mu \mathrm{mol} /$ 1. The antinuclear antibody (ANA) titre was 1:6400 with a homogenous pattern on immunofluorescence, but the DNA binding was normal and antibodies to ENAs were not detected. A minor salivary gland biopsy was consistent with Sjögren's syndrome. The serum levels of IgG and IgM were elevated (21.4 and $7.4 \mathrm{~g} / 1$ respectively), and tests for immune complexes (Clq binding and mRFBA) were strongly positive along with moderate cryoglobulinaemia. Serological tests for syphilis, hepatitis surface antigen and lupus anti-coagulant were all negative. Renal biopsy demonstrated a mesangio-proliferative glomerulonephritis 
with deposits of IgA, IgG, IgM and C3. The cerebrospinal fluid (CSF) was acellular with an elevated protein content $(1.09 \mathrm{~g} / \mathrm{l})$, but without oligoclonal $\mathrm{IgG}$ bands.

The motor nerve conduction velocities were moderately reduced at 43,46 and $31 \mathrm{~m} / \mathrm{s}$ on recording from the median, ulnar and peroneal nerves respectively. The median, ulnar and tibial nerve distal motor latencies were prolonged at $6.1,4.2$ and $8.5 \mathrm{~ms}$ respectively. The ulnar F-wave response was delayed $(38 \mathrm{~ms})$ and median and peroneal $\mathrm{F}$-waves were absent. The sensory nerve action potentials were small at 5,8 and $7 \mu \mathrm{V}$ on recording from the median, ulnar and sural nerves respectively. These findings were consistent with the diagnosis of acute inflammatory polyradiculoneuropathy (Eisen \& Humphreys, 1974).

The abductor pollicis brevis muscle action potential was small $(0.5 \mu \mathrm{V})$ but there was no evidence of conduction block in motor fibres of the median nerve. Reduction of the muscle action potential amplitude is considered to indicate poor prognosis in the GuillainBarré syndrome (Brown \& Feasby, 1984).

Prednisolone, $1 \mathrm{mg} / \mathrm{kg} /$ day, was started, but his condition deteriorated with increased sensory disturbance. He was given four, 5 litre plasma exchanges, followed by a single intravenous pulse of $500 \mathrm{mg}$ cyclophosphamide, and maintenance azathioprine was started. There was clinical improvement and by the time of discharge, power was in the MRC grade 44+ range. There was also a fall in the ESR and immunoglobulin levels, and renal function returned to normal. Nerve conduction studies 2 months after the onset of the illness showed improvement with motor nerve conduction velocities of 48 and $49 \mathrm{~m} / \mathrm{s}$ on recording from the median and ulnar nerves. The median nerve distal motor latency was $5 \mathrm{~ms}$ and the ulnar $4.3 \mathrm{~ms}$, and the F-wave latencies were less delayed (median $36 \mathrm{~ms}$, ulnar $35 \mathrm{~ms}$ ). The sensory nerve action potentials remained small (median $7 \mu \mathrm{V}$, ulnar $5 \mu \mathrm{V})$.

\section{Case 2}

In 1977 a 50 year old woman was admitted with epistaxes, and a profound thrombocytopenia $\left(15 \times 10^{6} / 1\right)$ with a mild normochromic normocytic anaemia. She gave a history of myalgia, arthralgia and fatigue over the 6 years prior to this. A diagnosis of SLE was made when she subsequently developed a florid polyarthritis with a raised ESR of $120 \mathrm{~mm} /$ hour, a positive ANA (1:640) and LE cell phenomenon. Treatment was initially prednisolone alone, but azathioprine was added later. On this combination she developed further purpura and, after bone marrow examination, azathioprine was implicated as the cause of thrombocytopenia and was discontinued.

In 1980 she complained of pain in both hips and X- rays showed bilateral osteonecrosis of the femoral heads. She underwent total hip replacement on the left in 1981 and on the right in 1983.

She was admitted in late 1983 with right upper quadrant abdominal pain and vomiting. Acute cholecystitis was diagnosed. The following week she developed progressive weakness in her arms and legs. Simultaneously, she noticed continuous tingling in the fingers and toes which spread proximally to the wrists and ankles over 5 days. There was no sphincter disturbance. On examination, she had global weakness of both arms (MRC grade 4 range), most marked in the extensor muscles, she could just flex her body against gravity with the truncal muscles, and she had global weakness of the legs (MRC grade 4) most marked in the flexors. Only the biceps tendon reflexes were retained and the plantar responses were flexor. There was hypaesthesia and hypalgesia of all fingers and both legs below the knees. Vibration sense was lost below the sternum, joint position sense was impaired in the fingers and toes and 2-point discrimination was of abnormally high threshold in the peripheries.

There was a mild normochromic normocytic anaemia $(\mathrm{Hb} 12.8 \mathrm{~g} / \mathrm{dl})$, and thrombocytopenia $\left(80 \times 10^{6} / 1\right)$. The ESR was $54 \mathrm{~mm} /$ hour and the DNA binding was normal with a positive ANA at $1: 160$. The CSF protein was raised $(1.1 \mathrm{~g} / \mathrm{l})$ with no cells or organisms present. The distal motor latencies orb recording from the median, ulnar and peroneal nerve were delayed at $7.8,5.6$ and $9.9 \mathrm{~ms}$ respectively. The median F-wave response was delayed at $42 \mathrm{~ms}$. The motor nerve conduction velocities were only slightly reduced (median nerve $46.5 \mathrm{~m} / \mathrm{s}$, ulnar nerve $48 \mathrm{~m} / \mathrm{s}$ ). The sensory nerve action potentials were absent. These findings were consistent with a diagnosis of acute inflammatory polyneuropathy (Eisen \& Humphreys, 1974).

The weakness gradually improved, and she was able to walk 8 weeks following the start of her illness despite no change in the maintenance dose of prednisolone.

\section{Discussion}

The Guillain-Barré syndrome (GBS), consisting of acute, usually predominantly motor neuropathy with areflexia and raised CSF protein, was first described in 1916 (Guillain et al.). Since then there has been controversy over diagnostic criteria, although guidelines have recently been proposed (Editorial, 1978). It is generally agreed that the eponym 'Guillain-Barré syndrome' should be reserved for those cases where an underlying aetiology is not found (Marshall, 1963; Asbury, 1981), the remainder being called 'acute inflammatory polyradiculoneuropathy'. In a large literature review of 1,100 cases of 'Guillain-Barré 
syndrome' (Leneman, 1966), 66\% had an established associated illness. Of these, only 14 (less than $2 \%$ ) were related to a connective tissue disease; SLE having been diagnosed in 7 cases. This emphasizes that polyradiculoneuropathy rarely complicates SLE, and may appear by chance alone.

The patients presented are unusual in that they developed SLE at a late age. McDonald et al. (1984) have suggested that neurological complications of SLE are more common in patients presenting late in life. They also proposed that this may be due to damage to the blood-brain barrier by cerebro-vascular disease, allowing antineuronal antibodies, often present in patients with SLE (Bresnihan et al., 1977, 1979), access to the nervous system. However, the permeability of the blood-brain barrier is increased in active SLE in isolation (Atkins et al., 1972) and local synthesis of antibodies within the nervous system probably occurs (Harbeck et al., 1979).

Although the pathogenesis of GBS is unknown, there is growing evidence to suggest both humoral (Cook \& Dowling, 1981; Latov et al., 1981; Vedeler et al., 1982) and cell-mediated (Iqbal et al., 1981) immune mechanisms. Many patients have raised immunoglobulin and acute-phase protein levels, as well as antibodies to peripheral nerve components (Iqbal $e t$ al., 1981), however antineuronal antibodies may be found in the sera of patients with SLE who do not have evidence of a neuropathy (Bresnihan et al., 1977, 1979). Idiopathic GBS may be complicated by more diffuse systemic features of immunologically mediated disease, including acute glomerulonephritis

\section{References}

ARNASON, B.G.W. (1984). Acute inflammatory polyradiculoneuropathy. In Peripheral Neuropathy, 2nd Edition, Dyck, P.J., Thomas, P.K., Lambert, E.H. and Bunge, R. (eds). p. 2050. Saunders: Philadelphia.

ASBURY, A.K. (1981). Diagnostic considerations in the Guillain-Barré syndrome. Annals of Neurology, 9 (suppl), 1.

ATKINS, C.J., KONDON, J.J., QUIJMORIO, F.P. \& FRIOU, G.J. (1972). The choroid plexus in systemic lupus erythematosus. Annals of Internal Medicine, 76, 65.

BRESNIHAN, B., OLIVER, M., GRIGOR, R. \& HUGHES, G.R.V. (1977). Brain reactivity of lymphocytotoxic antibodies in systemic lupus erythematosus with and without cerebral involvement. Clinical and Experimental Immunology, 30, 333.

BRESNIHAN, B., OLIVER, M., WILLIAMS, B. \& HUGHES, G.R.V. (1979). An antineuronal antibody cross reacting with erythrocytes and lymphocytes in systemic lupus erythematosus. Arthritis and Rheumatism. 22, 313.

BROWN, W.F. \& FEASBY, T.E. (1984). Conduction block and denervation in Guillain-Barré polyneuropathy. Brain, 107, 219.

CATOGGIO, L.J., R.P., SMITH, G. \& MADDISON, P.J. (1984). Systemic lupus erythematosus in the elderly, clinical and
(Rodriquez-Iturbe et al., 1973).

Both patients satisfy the revised ARA criteria for the diagnosis of SLE (Tan et al., 1982), although neither had antibodies against double stranded DNA (dsDNA), or ENAs, despite the high titre of antinuclear antibodies by indirect immunofluorescence. Interestingly, low titres of anti-dsDNA have previously been described in elderly patients with SLE, although this does not correlate with neurological involvement (McDonald et al., 1984; Catoggio et al., 1984; Wilson et al., 1981).

There is still controversy over the management of GBS or acute inflammatory polyradiculoneuropathy, and the influence of immunosuppressive agents (Arnason, 1984) or plasma exchange (Hughes, 1985). When the syndrome is associated with active SLE, the treatment is that of the underlying disease, and there is evidence that plasma exchange in this circumstance may have a beneficial effect on the neuropathy (Hughes et al., 1982).

Current recommendation is that if acute polyradiculoneuropathy occurs in a patient with an active connective tissue disorder, then immunosuppression as well as plasma exchange should be given. If the underlying disease is quiescent, such measures are probably not justified.

\section{Acknowledgements}

We would like to thank Dr A.E. Harding for performing the electrophysiological studies.

serological characteristics. Journal of Rheumatology, 11, 175.

COOK, S.D. \& DOWLING, P.C. (1981). The role of antibodies and immune complexes in the pathogenesis of GuillainBarré syndrome. Annals of Neurology, 9 (suppl), 70.

EDITORIAL. (1978). Criteria for the diagnosis of GuillainBarré syndrome. Annals of Neurology, 3, 565.

EISEN, A. \& HUMPHREYS, P. (1974). The Guillain-Barré syndrome. A clinical and electrodiagnostic study of 25 cases. Archives of Neurology, 30, 438.

GRIGOR, R., EDMONDS, S., LEWKONIA, R., BRESNIHAN, B. \& HUGHES, G.R.V. (1978). Systemic lupus erythematosus, a prospective analysis. Annals of Rheumatic Diseases, 37, 121.

GUILlAIN, G., BARRE, J.A. \& STROHL, A. (1916). Sur un syndrome de radiculo- neurite avec hyperalbuminoise du liquide cephalorachidien sans reaction cellulaire. Remarques sur les characteres cliniques et graphiques des reflexes tendineux. Bulletin de la Sociéte Médecine de Paris, 40, 1462.

HARBECK, R.J., HOFFMAN, A., HOFFMAN, S.A. \& SHUARD, D.W. (1979). Cerebro-spinal fluid and the choroid plexus during acute immune complex disease. Clinical Immunology and Immunopathology, 13, 413. 
HUGHES, R.A.C., CAMERON, J.S., HALL, S.M., HEATON, J., PAYAN, J. \& TEOH, R. (1982). Multiple mononeuropathy as the initial presentation of systemic lupus erythematosus. Journal of Neurology, 228, 239.

HUGHES, R.A.C. (1985). Plasma exchange for Guillain-Barré syndrome. British Medical Journal, 291, 615.

IQBAL, A., OGER, J.J.-E. \& ARNASON, B.G.W. (1981). Cellmediated immunity in idiopathic polyneuritis. Annals of Neurology, 9 (suppl), 65.

JOHNSON, R.T. \& RICHARDSON, E.P. (1968). The neurological complications of systemic lupus erythematosus. Medicine, 47, 337.

KAPOSI, M. (1872). Neu beitrage sur kenntnis des lupus erythematosus. Archiv Dermatologie und Syphilis, 4, 36.

LATOV, N., GROSS, R.B., KASTELMAN, J., FLANIGAN, T., LAMME, F., ALKAITIS, D.A., OLARTE, M.R., SHERMAN, W.H., CHESS, L. \& PENN, A.S. (1981). Complement fixing antiperipheral nerve myelin antibodies in patients with inflammatory polyneuritis and with polyneuropathy and paraproteinaemia. Neurology (NY), 31, 1530.

LENEMAN, F. (1966). The Guillain-Barré syndrome. Archives of Internal Medicine, 118, 139.

MARSHALL, J. (1963). The Landre-Guillain-Barré syndrome. Brain, 86, 55 .
MCDONALD, K., HUTCHINSON, M. \& BRESNIHAN, B. (1984). The frequent occurrence of neurological disease in patients with late onset systemic lupus erythematosus. British Journal of Rheumatology, 23, 186.

RODRIQUEZ-ITURBE, B., GARCIA, R. RUZIO, L., ZABALA, J., MOROS, G. \& TORRES, R. (1973). Acute glomerulonephritis in Guillain-Barré syndrome, a report of nine cases. Annals of Internal Medicine, 78, 391.

TAN, E.M., COHEN, A.S., FREIS, J.F., MAISI, A.T., McSHANE, D.J., ROTHFIELD, N.F., SCHALLER, J.G., TALLAL, N. \& WINCHESTER, R.J. (1982). The 1982 revised criteria for the classification of systemic lupus erythematosus. Arthritis and Rheumatism, 25, 1271.

VEDELER, C.A., NYLAND, H. \& MATRE, R. (1982). Antibodies to peripheral nerve tissue in sera from patients with Guillain-Barré syndrome demonstrated by a mixed haemagglutination technique. Journal of Neuroimmunology, 2, 209.

WILSON, H.A., HAMILTON, M.E., SPYKER, D.A., BRUNNER, C.M., O'BRIEN, W.M., DAVIS IV, J.S. \& WINFIELD, J.B. (1981). Age influences the clinical and serological expression of systemic lupus erythematosus. Arthritis and Rheumatism, 24, 1230. 